Canadian Science Publishing

Applied Physiology, Nutrition, and Metabolism Physiologie appliquée, nutrition et métabolisme

\title{
EFFECTS OF HIGH PROTEIN INTAKE ON BONE TURNOVER IN LONG-TERM BED REST IN WOMEN
}

\begin{tabular}{|r|l|}
\hline Journal: & Applied Physiology, Nutrition, and Metabolism \\
\hline Manuscript ID & apnm-2016-0292.R4 \\
\hline Manuscript Type: & Article \\
\hline Date Submitted by the Author: & 22-Dec-2016 \\
\hline Complete List of Authors: & $\begin{array}{l}\text { Heer, Martina; University of Bonn, Institute of Nutrition and Food Sciences } \\
\text { Baecker, Natalie; University of Bonn, Department of Nutrition and Food } \\
\text { Science } \\
\text { Frings-Meuthen, Petra; German Aerospace Center (DLR), Institute of } \\
\text { Aerospace Medicine } \\
\text { Graf, Sonja; University of Bonn, Institute of Nutrition and Food Sciences } \\
\text { Zwart, Sara; University of Texas Medical Branch at Galveston } \\
\text { Biolo, Gianni; University of Trieste, Division of Internal Medicine } \\
\text { Smith, Scott; NASA Lyndon B. Johnson Space Center, Human Health and } \\
\text { Performance Directorate }\end{array}$ \\
\hline \hline Keyword: & High protein intake, Bed rest, Bone turnover, Branched chain amino acids \\
\hline \multicolumn{2}{|c}{} \\
\hline
\end{tabular}




\section{EFFECTS OF HIGH PROTEIN INTAKE ON BONE TURNOVER IN LONG-TERM BED REST IN WOMEN}

Martina Heer ${ }^{a}$, Natalie Baecker ${ }^{\mathrm{a}}$, Petra Frings-Meuthen ${ }^{\mathrm{b}}$, Sonja Graf ${ }^{\mathrm{a}}$, Sara R. Zwart ${ }^{\mathrm{c}}$, Gianni Biolo $^{d}$, Scott M. Smith

${ }^{a}$ Department of Nutrition and Food Sciences, Nutritional Physiology, University of Bonn, Germany

${ }^{\mathrm{b}}$ German Aerospace Center (DLR), Institute of Aerospace Medicine, Cologne, Germany

${ }^{\mathrm{c}}$ University of Texas Medical Branch, Galveston, Texas, USA

${ }^{d}$ Department of Clinical, Technological and Morphological Sciences, Division of Internal Medicine, University of Trieste, Italy

e Human Health and Performance Directorate, NASA Lyndon B. Johnson Space Center, Houston, Texas, USA

Abbreviated title: Immobility, high protein intake and bone turnover

Corresponding author:

Martina Heer, PhD

University of Bonn

Institute of Food and Nutrition Sciences

53115 Bonn

Germany

Tel: +49228732021

Fax: +49 228733217

E-mail: drmheer@aol.com 


\section{ABSTRACT}

Purpose: Bed rest (BR) causes bone loss, even in otherwise healthy subjects. Several studies suggest that ambulatory subjects may benefit from high protein intake to stimulate protein synthesis and to maintain muscle mass. However, increasing protein intake above the recommended daily intake without adequate calcium- and potassium intake may increase bone resorption. We hypothesized that a regimen of high protein intake (HiPROT), applied in an isocaloric manner during BR with calcium and potassium intake meeting recommended values, would prevent any effect of BR on bone turnover. Methods: After a 20-day ambulatory adaptation to a controlled environment, 16 women participated in a 60 -day, $6^{\circ}$ head-down-tilt (HDT) BR and were assigned randomly to one of two groups. Control (CON) subjects $(n=8)$ received $1 \mathrm{~g} / \mathrm{kg}$ body mass $/ \mathrm{d}$ dietary protein. HiPROT subjects $(n=8)$ received $1.45 \mathrm{~g}$ protein $/ \mathrm{kg}$ body mass $/ \mathrm{d}$ plus an additional $0.72 \mathrm{~g}$ branched-chain amino acids (BCAA) per day during BR. All subjects received an individually tailored diet (before HDTBR: $1888 \pm 98 \mathrm{kcal} / \mathrm{d}$; during HDTBR: $1604 \pm 125 \mathrm{kcal} / \mathrm{d}$; after HDTBR: $1900 \pm 262 \mathrm{kcal} / \mathrm{d}$ ), with the CON group's diet being higher in fat and carbohydrate intake. Results: High protein intake exacerbated the BR-induced increase in bone resorption marker C-telopeptide ( $>30 \%)$ $(p<0.001)$ by the end of BR. Bone formation markers were unaffected by BR and high protein intake. Conclusion: We conclude that high protein intake in BR might exaggerate bone loss. Further long-duration studies are mandatory to show how the positive effect of protein on muscle mass can be maintained without the risk of reducing bone mineral density.

Keywords: High protein intake, Bed rest, Bone turnover, Branched chained amino acids 


\section{INTRODUCTION}

Reduced mechanical loading caused by bed rest $(\mathrm{BR})$ or spaceflight leads to dramatic losses in bone (Lang et al. 2004) and in muscle mass and strength (Biolo et al. 2004; Ferrando et al. 1996). This is one of the major risks for developing osteoporosis and sarcopenia in bedridden or immobile elderly people as well as astronauts. In addition to the decreased mechanical load, nutrient intake may have profound effects on the health of the musculoskeletal system. Malnutrition could exacerbate bone and muscle loss when the system is faced with insufficient intakes of energy, protein, calcium, or vitamin D (Biolo et al. 2007; Ihle \& Loucks 2004). Increasing particular nutrients such as protein by supplementing branched-chain amino acids or whey protein may provide beneficial effects on muscle protein synthesis (Antonione et al. 2008; Biolo et al. 1995; Smith et al. 2012, English \& Paddon-Jones 2010).

Clearly, dietary protein provides amino acid precursors required for synthesis and maintenance of bone structure (Bonjour 2005; Kerstetter et al. 2011; Rouy et al. 2014). But, it has been hypothesized that dietary protein in excess of the body's needs can contribute to acid production and the development of low-grade metabolic acidosis (Remer \& Manz 1995), which may lead to increased bone resorption and release of calcium from bone (Nicoll \& McLaren 2014). Resulting hypercalciuria may increase risk of renal stone formation and fracture (Dawson-Hughes 2003, Alexy et al. 2005; Buclin et al. 2001; Campbell \& Tang 2010; Massey 2003). One hypothesis to explain protein-induced hypercalciuria is related to the "acid-ash" hypothesis; that is, excessive intake of protein beyond the body's requirement provides excess sulfur-containing amino acids that, when oxidized, yield sulfuric acid (Kraut \& Coburn 1994). The basis for the acid-ash hypothesis is that animal protein is considered to contain more of sulfur- and phosphate containing amino acids than plant protein contains. Metabolism of sulfur- and phosphate containing amino acids leads to a transient reduction in extracellular $\mathrm{pH}$ and this can be countered by the ingestion of base precursors, typically 
associated with potassium salts (Ginty 2003; Heaney \& Layman 2008; Jehle et al. 2006; Massey 2003; Nicoll \& McLaren 2014; Remer et al. 2014).

The acid-ash hypothesis is under debate and there are several studies and reviews claiming that no cause- and- effect relationship exists between consumption of dietary acid precursors and bone health (Cao et al. 2014; reviewed in Fenton et al. 2009 and Fenton et al. 2011). Other studies demonstrated that a diet with lower potential renal acid loads may positively affect bone turnover (Buclin et al. 2001; Lanham-New et al. 2008; Wynn et al. 2010) and bone mineral density (BMD) (MacDonald et al. 2005; New et al. 2004). The majority of these studies have not been carried out in a metabolic ward. The advantage of metabolic ward conditions are that they allow to modify only one variable and keep the other impact factors constant and thereby demonstrate a cause-and-effect relationship. One of the disadvantages is that they are very expensive and can't be applied if a parameter only slowly changing over time, for instance fracture risk, is the main outcome parameter. In such a metabolic ward setting in BR, Zwart et al have examined bone turnover and shown that in BR but not during an ambulatory pre-BR phase, higher animal protein intake $(1.6 \mathrm{~g} / \mathrm{kg} \mathrm{BM} / \mathrm{d})$ relative to potassium intake was associated with more bone resorption indices and urinary excretion of calcium (Zwart et al. 2004).

To our knowledge only two clinical trials have examined the effect of high protein intake on bone while actively considering other important factors such as calcium, sodium, energy, and vitamin $\mathrm{D}$ intake, consumption of fruits and vegetables, total caloric intake, and the source and amino acid composition of protein, in addition to ambulation or exercise status (Hunt et al. 2009; Thorpe et al. 2008a). In a 7-week prospective study in postmenopausal women (Hunt et al. 2009), Hunt et al. demonstrated that an increase in protein intake-when protein was mainly animal protein-from $10 \%$ to $20 \%$ of energy intake does not affect bone health. Thorpe et al. (2008a) demonstrated, in a study in which BMD was measured in postmenopausal women and dietary intake was obtained by a 24-hour recall method, that 
protein intake was positively associated with areal BMD in postmenopausal women. This association, however, was suppressed by a negative association of sulfur from amino acids with areal BMD at the lumbar spine.

The effect of high protein intake on bone metabolism and bone mass seems to be either neutral or positive in ambulatory conditions (reviewed in Bonjour 2016; Kerstetter et al. 2011). The Institute of Medicine (IOM) recommended level of protein intake for adults is $0.8 \mathrm{~g}$ /kg BM/d (Institute of Medicine 2002). To overcome reduction in muscle protein synthesis increasing daily protein intake to levels about 1.0-1.2 (moderately high) (Bauer et al. 2013) and $1.2-1.5 \mathrm{~g} / \mathrm{kg} \mathrm{BM} / \mathrm{d}$ (high) or between 15 and $20 \%$ of the daily energy intake (Deutz et al. 2014; Wolfe et al. 2008) are recommended for older people. In line with several authors who studied the effect of protein intake on bone metabolism (Alexy et al. 2005; Bonjour 2016; Campbell \& Tang 2010; Fenton et al. 2009; Kerstetter et al.1997; Kerstetter et al. 2003a; Kerstetter et al. 2003b), we also define protein intake of 1.3 to $2.1 \mathrm{~g} / \mathrm{kg} \mathrm{BM} / \mathrm{d}$ as high protein intake. A moderately high protein intake would range from 0.9 to $1.2 \mathrm{~g} / \mathrm{kg} \mathrm{BM}$ per day, similar to the definition by Kerstetter et al. (2003a) who defined a diet containing $1.0 \mathrm{~g} / \mathrm{kg} \mathrm{BM} / \mathrm{d}$ protein as moderate. If the effects of high protein intake are positive in ambulatory conditions where the musculoskeletal system is mechanically loaded, it is still not clear whether, in conditions where osteoclasts are activated as in $\mathrm{BR}$, increasing protein intake beyond IOM recommendations might also have positive effects on bone. Therefore the question remains: how does increasing protein intake during $\mathrm{BR}$ - where this could mitigate the decrease in protein synthesis and muscle mass and strength and may have insulinotropic effects (Frid et al. 2005; Rietman et al. 2014) that may compensate for a reduced glucose tolerance in BR (Alibegovic et al. 2009; Yanagibori et al. 1997) _affect bone? High-quality protein products and branched-chain amino acids seem to have the most beneficial effect on muscle (English \& Paddon-Jones 2010). Given that a positive effect such as maintaining muscle mass by maintaining muscle protein synthesis (English et al. 2016; Moore 2014) would be very beneficial in inactivity such as BR, increased protein intake might still increase bone 
resorption processes. However, as mentioned earlier, such an effect of hypothesized increased bone resorption processes might be mitigated by providing recommended amounts of calcium in the daily diet (Bowen et al. 2004; Dawson-Hughes 2003; Sahni et al. 2010). We therefore hypothesized in the present study that increasing total protein intake during inactivity such as BR while providing intakes of calcium and other nutrients at recommended levels (Institute of Medicine 2004; Institute of Medicine 2011) would be beneficial for bone health. 


\section{MATERIALS AND METHODS}

This study (Women in Space Exploration study, WISE) was a multinational effort among several space agencies to conduct an intensive study of selected countermeasures against BR-induced losses of bone and muscle mass, aerobic capacity, orthostatic tolerance, and muscle performance. We report here the effect of high protein intake along with amino acid supplementation during long-term head-down tilt (HDT) BR on bone metabolism in women. The larger study included another treatment group testing an exercise regimen during a 60day HDTBR. The results of that study have been published (Smith et al. 2008), including the control subject data. Many other aspects (e.g., cardiovascular, muscle, BMD) of the treatment with exercise and high protein intake have also been published (Arbeille et al. 2007; Arbeille et al. 2008; Armbrecht et al. 2011; Beavers et al. 2007; Beller et al. 2011; Edgell et al. 2007; Gagne et al. 2007; Guinet et al. 2009; Hodges et al. 2010; Kerbeci et al. 2007; Schneider et al. 2009; Zuj et al. 2007), but the findings reported here regarding effects of protein on bone turnover markers have not been previously published.

\section{Subjects}

Sixteen healthy, nonsmoking female subjects (mean \pm SD $32.4 \pm 3.7 \mathrm{y}, 166.5 \pm 6.8 \mathrm{~cm}$, $59.0 \pm 5 \mathrm{~kg}$ ) volunteered to participate in the study. Subjects were excluded if they had used oral contraceptives in the 2 months before the study. In brief, inclusion criteria for the subjects included body mass index $20-25 \mathrm{~kg} \bullet \mathrm{m}^{-2}$, regular menstrual cycles, no family history of chronic or acute disease, and active lifestyle. The exclusion criteria were any orthopedic, musculoskeletal, or cardiovascular disorders. The full list of inclusion and exclusion criteria is in the publication of Trudel et al. (Trudel et al. 2009). The protocol for this study was approved by the local ethics committee (CCPPRB of Toulouse, France), along with the Ethics Review Board Ärztekammer Nordrhein, Duesseldorf, Germany, and many other partner review boards. Subjects provided written informed consent before participating. 
Study design

The parallel-design study was conducted at the Institute for Space Physiology and Medicine (MEDES) in Toulouse, France. It consisted of a 20-day ambulatory in-house control period (pre-HDTBR, day-10 to day-1) followed by 60 days of $-6^{\circ}$ HDTBR (HDTBR day 1 to HDTBR day 60). A 20-day ambulatory in-house recovery (post HDTBR, recovery day 1 to recovery day 20) period followed the BR period.

Subjects were recruited for two different HDTBR campaigns (campaign 1: Feb-May 2005, campaign 2: Sept-Dec 2005). Subjects were matched according to pre-HDTBR aerobic fitness levels, and then assigned randomly to either the control $(\mathrm{CON}, \mathrm{n}=8)$ or the high protein intake (HiPROT, n=8) group. The CON subjects performed no countermeasures during HDTBR. During the HDTBR phase, the HiPROT subjects received, relative to the control group, an additional $0.45 \mathrm{~g} / \mathrm{kg} \mathrm{BM} / \mathrm{d}$ protein (mainly animal protein) in their diet, provided isocalorically. This protein consisted mainly of milk and milk products, a protein powder (Hyperprotéiné, Beaubour Nutrition, France), plus an amino acid supplement (with each main meal, one bag Friliver®, $10 \mathrm{~g}$ each) containing $0.12 \mathrm{~g}$ of leucine, $0.06 \mathrm{~g}$ of isoleucine, and $0.06 \mathrm{~g}$ of valine. The nominal diet for both groups included $1.0 \mathrm{~g}$ protein $/ \mathrm{kg}$ $\mathrm{BM} / \mathrm{d}$, and thus the HiPROT group consumed a total of $1.45 \mathrm{~g}$ protein/kg BM/d plus a supplement of branched-chain amino acids (BCAA) of $0.72 \mathrm{~g}$ per day resulting in about $22 \%$ of daily energy intake being protein. The protein content of the regular diet was $62 \%$ from animal sources and $38 \%$ from vegetable sources. Actual nutrient intake data are listed in Table 1.

Diet and metabolic rate

Resting metabolic rate (RMR) was analyzed during the 20 days before HDTBR by indirect calorimetry (Deltatrac ${ }^{\mathrm{TM}}$ II, Datex Ohmeda, Inc, Madison, WI, USA). During the ambulatory phases (pre-HDTBR and post HDTBR) subjects received dietary energy intake equal to 
$140 \%$ of the RMR to match the light physical activity lifestyle in these phases of the study. For the HDTBR phase, for both groups the initial caloric intake was set at $125-140 \%$ of the average pre-HDTBR RMR to take into account the lower energy expenditure in BR. During HDTBR every 15 days, RMR was determined by indirect calorimetry. Body mass was monitored daily using a bed scale. The goal of this design was to allow subjects to lose muscle mass during HDTBR, but to maintain their body fat stores to avoid any impact of changes in fat mass on any outcome parameter. This was achieved by monitoring daily body mass and energy intake from pre-HDTBR days -14 to -1 . When losses of body mass occurred, the assumption was that $75 \%$ and $25 \%$ of weight loss were accounted for by fat and lean tissue mass, respectively. Half of the calculated value of the energy content in the fat mass lost in $\mathrm{kcal} / \mathrm{d}$ was added to the daily energy requirement. The final values of the daily energy requirement were then adapted to the estimated requirement in HDTBR.

Subjects were provided three meals per day, and up to two snacks. Average daily intake of the macronutrients as well as some minerals is listed in Table 1. The daily menu of both the control and the HiPROT intake groups was composed of regular food ingredients. A typical daily menu and a list of typical ingredients are shown in Tables $2 a$ and $2 b$. Sodium intake was kept at 1.2-1.6 mmol/kg BM/d and potassium intake at 0.9-1.1 mmol/kg BM/d; calcium intake in the CON group during the intervention period was $889 \pm 154 \mathrm{mg} / \mathrm{d}$, while the HiPROT group received $1291 \pm 170 \mathrm{mg} / \mathrm{d}$ (Table 1). These levels meet the recommended dietary allowances (RDA) by the National Institute of Medicine (Institute of Medicine 2011), which are based on the nutrient composition of Western diets. These diets are considered to contain a protein content of on average 1.0 to $1.5 \mathrm{~g} / \mathrm{kg} \mathrm{BM} / \mathrm{d}$ (Heaney \& Layman 2008; Kerstetter et al. 2003b), which is close to the amount we provided in the present study. Phosphorus intake was kept at 1.2-1.6 mmol/kg BM/d. Subjects were restricted from ingesting food and beverage products containing methylxanthine and alcohol during the study. Subjects were not forced to consume $100 \%$ of their provided meals. Leftovers were weighed and actual individual nutrient intake was calculated. 
Body composition

Total body fat and lean mass were measured by dual-energy $x$-ray absorptiometry (DEXA) (HOLOGIC QDR 4500 Elite $囚$ ) before HDTBR, after about 30 days of HDTBR, and 3 days after reambulation $(R+3)$. Scans of each volunteer's total body lean and fat mass were acquired in triplicate before and after HDTBR. Triplicate measures at each time point were averaged before the statistical analysis was done. The midstudy (30 d) DEXA was performed with one scan. All DEXA scans were acquired by the same operator to ensure consistency of positioning and measures. Body composition data derived from the software of the HOLOGIC QDR 4500 Elite® were used for analyses.

\section{Biological samples}

Biological samples (fasting [ $>10 \mathrm{~h}$ ] blood samples and two 24-h urine pools) were collected twice before HDTBR (between day-10 and day-1), two (blood) or three (urine) times during HDTBR (urine only on HDTBR day14/HDTBR day15, and both collected between HDTBR day28 and HDTBR day32, and again between HDTBR day56 and HDTBR day60), and once after HDTBR ended (between 5 and 7 days after $B R$, days $R+5$ and $R+7$ ) for the measurement of markers of bone and calcium metabolism. Blood samples were collected immediately after subjects awakened, at the same time of day, to minimize the effects of diurnal changes in endocrine and biochemical markers. Blood and urine were processed and frozen in respective aliquots for each analyte at $-80^{\circ} \mathrm{C}$ until they were analyzed.

Biochemical analyses

With the exception of tartrate-resistant alkaline phosphatase (TRAP), samples from both campaigns were assayed at the same time to minimize inter-assay variations in the results. All biochemical analyses except TRAP were performed immediately after the second campaign of the study was completed, using standard commercial techniques as previously described (Baecker et al. 2003; Smith et al. 2012; Smith et al. 2014). Circulating bone- and 
calcium-related factors were measured in serum. Samples from all subjects were analyzed at the same time and samples from one subject one after another to avoid interassay variation. Only continuously frozen and no previously thawed samples were used for the analyses. Parathyroid hormone (PTH) was assayed for the intact peptide by radioimmunoassay (RIA) (Nichols Institute Diagnostics, San Juan Capistrano, CA, USA, and DSL, Stillwater, MN, USA). Insulin-like growth factor 1 (IGF-1) was analyzed by RIA (Alpco Diagnostics, Salem, $\mathrm{NH}$, USA). Serum 25-hydroxyvitamin D was determined by RIA after extraction with acetonitrile (DiaSorin, Stillwater, MN, USA). Markers of bone formation, including N-terminal procollagen-I propeptide (PINP; Orion Diagnostica, Finland), bone-specific alkaline phosphatase (bAP: Quidel Corporation, Santa Clara, CA) and osteocalcin (Biomedical Technologies, Stoughton, MA, USA), were measured using enzyme-linked immunosorbent assay (ELISA) and RIA techniques. TRAP, a marker for bone resorption, was analyzed by commercially available ELISA (SBA SciencesBioCity, Turku, Finland). The samples from the two study campaigns weren't analyzed for TRAP in one batch of the assay; the samples from the first study campaign were analyzed immediately after the first campaign and the samples from the second campaign were analyzed immediately after the second campaign. The urinary collagen crosslinks N-telopeptide (NTX) and C-telopeptide (CTX), which are also markers of bone resorption, were measured using commercially available kits (NTX: Osteomark, Wampole Laboratories, Princeton, NJ, USA; CTX: Crosslaps, Osteometer BioTech, Herlev, Denmark). In contrast to TRAP, CTX and NTX were analyzed consecutively for each subject, using assays from a single batch for all analyses. Data for control subjects have been previously published for serum calcium, PTH, 25-hydroxyvitamin D, PINP, bAP, and osteocalcin.

\section{Statistical analysis}

Data were analyzed using repeated-measures ANOVA techniques, and using ANOVA for post hoc testing also. Between-treatment comparisons were done using ANOVA with [corresponding parameter as response] treatment, day, and treatment by day interaction as 
fixed effects, and subject as a random effect. For urine parameters NTX excretion and urine volume, an analysis of covariance (ANCOVA) was performed, adding the baseline value as a covariate to the model. Within-treatment comparisons were done for each treatment using ANOVA with [corresponding parameter as response], day as a fixed effect, and subject as a random effect. Normal distribution of the data was tested. Statistical analyses were performed using SAS® software, version 9.3 (2011). Statistical significance was defined as $p<0.05$. 


\section{RESULTS}

Body mass was significantly different between groups before HDTBR ( $p=0.02$, Figure 1$)$. It decreased by $3.4 \mathrm{~kg}$ during HDTBR in the CON group and by $2.9 \mathrm{~kg}$ in the HiPROT group, with a trend of a more pronounced decrease in the CON group $(p=0.09)$. Total lean body mass was also significantly different between groups before HDTBR $(p=0.04$, Figure 1$)$, but decreased by $1.7 \mathrm{~kg}$ in both groups during HDTBR. Total fat mass was not different before HDTBR. However, during HDTBR fat mass decreased by $0.8 \mathrm{~kg}$ in the CON while it stayed almost stable $(-0.2 \mathrm{~kg})$ in the HiPROT group $(p=0.04$, Figure 1$)$.

Head-down tilt BR increased urinary bone resorption markers CTX, NTX, and TRAP, as well as urinary calcium excretion, relative to baseline (CTX, $p<0.001$ (Figure 2); NTX, $p=0.001$ (Figure 2); TRAP, $p<0.001$ (Table 3); urinary calcium excretion $\left[\mathrm{U}_{\mathrm{Ca}} \mathrm{V}\right], \mathrm{p}=0.003$ (Figure 2)). When groups were compared, HiPROT was associated with significantly greater amounts of bone resorption markers (CTX, $p<0.001$; NTX, $p=0.001$; UCaV, $p<0.001)$ in HDTBR than was CON (Figure 2).

Unlike serum calcium concentration, neither phosphate, IGF-1, PTH, 25-hydroxyvitamin D, PINP, bAP, nor osteocalcin concentration was different between the groups before HDTBR (Table 3). Head-down tilt BR induced a significant increase in serum calcium concentration $(p=0.001)$ relative to baseline, whereas high protein intake had no effect $(p=0.10)($ Table 3$)$.

Serum phosphate levels significantly increased in HDTBR $(p<0.001)$ in both groups, but there was no significant effect of high protein intake (Table 3).

The concentration of IGF-1 significantly increased during HDTBR $(p<0.01)$ in both groups. There was a trend for the HiPROT group to have higher concentrations, and a greater increase during HDTBR, but these did not reach statistical significance (treatment: $p=0.08$; time-treatment interaction: $\mathrm{p}=0.06)($ Table 3)). 
PTH decreased during BR $(p=0.02)$ whereas high protein intake had no effect on PTH concentrations. 25-hydroxyvitamin D concentrations only showed a trend of decreasing during HDTBR ( $p=0.06$ ), but high protein intake didn't affect 25-hydroxyvitamin D concentrations (Table 3).

Regarding bone formation markers, only PINP increased over time because of HDTBR $(p=0.001)$. Bone-specific alkaline phosphatase and osteocalcin were not affected by either HDTBR or high protein intake in HDTBR (Table 3). 


\section{DISCUSSION}

In the present study we have shown that increasing protein intake from a higher level $(1.0 \mathrm{~g} / \mathrm{kg} \mathrm{BM} / \mathrm{d})$ than the dietary reference intake $(0.8 \mathrm{~g} / \mathrm{kg} \mathrm{BM} / \mathrm{d}$ for adults (Food and Nutrition Board \& Institute of Medicine 2005)) to about $1.6 \mathrm{~g} / \mathrm{kg} \mathrm{BM} / \mathrm{d}$ including supplementation of BCAA ( $0.72 \mathrm{~g}$ per day) in healthy young women bed rested for 60 days - while keeping a ratio of $60 \%$ animal protein intake to $40 \%$ vegetable protein intake and ensuring adequate calcium intake —still led to significant exacerbation of bone resorption markers during HDTBR. Bed rest alone induced a 55\% increase in urinary $\mathrm{Ca}$, a $70 \%$ increase in CTX excretion, and a $62 \%$ increase in NTX excretion, while the HiPROT diet led to $15 \%$ higher urinary $\mathrm{Ca}, 30 \%$ higher CTX excretion, and $5 \%$ higher NTX excretion relative to CON during HDTBR. These data suggest that the higher protein intake increased osteoclast activity and might exacerbate long-term risk for bone loss in bed-ridden people.

It is noteworthy that the level of bone resorption marker excretion was greater in the HiPROT group than in the CON group during the baseline period before HDTBR. One could speculate that the HiPROT group had a higher level of exercise supporting muscle strength before entering the laboratory and the reduction in mechanical loading before HDTBR might have induced an increase in bone resorption markers. But physical fitness levels for the two groups seemed to be comparable, judging by peak $\mathrm{VO}_{2}$ values measured during bicycle ergometer exercise (Schneider et al. 2009),

The higher calcium intake in the HiPROT group could have affected calcium excretion. This higher dietary calcium content was caused by increased amounts of milk products - which usually have higher calcium levels_-, protein powder, and BCAAs used to increase protein intake. However, in light of the results from a previous study (Baecker et al. 2010), in which doubling calcium intake (from 1000 to 2000 mg/d) did not affect bone resorption markers, we presumed that the slightly higher dietary calcium content in the HiPROT group did not affect bone turnover. 
When taking into account an average calcium absorption rate of $24 \%$ in the HDTBR phase, as measured with isotope techniques by LeBlanc et al. (LeBlanc et al. 1995), an additional $97 \mathrm{mg}$ of calcium per day might have been absorbed in the HiPROT group. This would match the higher average urinary calcium excretion of $97 \mathrm{mg}$ of calcium per day. However, this estimate presumes a linear increase in calcium absorption with higher calcium intake, which might not be the case when increasing dietary calcium intake above the recommended level (Murray 1996).

The increase in urinary calcium excretion is in line with the higher excretion of bone resorption markers CTX and NTX as well as the lower cortical thickness observed in the HiPROT group (Armbrecht et al. 2011), suggesting that some of the higher amount of urinary excreted calcium truly originated from bone.

Kerstetter et al. (Kerstetter et al. 2005) have shown in healthy ambulatory women by a dual stable isotope technique that an increase in protein intake from 1.0 to $2.1 \mathrm{~g} / \mathrm{kg}$ body mass $/ \mathrm{d}$ for 10 days increased calcium absorption and induced increased urinary calcium excretion without having any effect on net bone balance. One might argue that this would also be true for bed-rested subjects. However, in BR, as in this study, serum calcium levels often increase and serum PTH and 1,25 (OH $)_{2}$ cholecalciferol concentrations decrease (Arnaud et al. 1992; Inoue et al. 2000; Morgan et al. 2014; van der Wiel et al. 1991; Zerwekh et al. 1998), effects that in general result in reduced calcium bioavailability. Since measuring calcium absorption was not a goal of our experiment, we did not apply dual isotope techniques to measure true calcium absorption. Therefore, we cannot derive from the present study whether—under these circumstances—high protein intake induced changes in calcium absorption rates. However, it does not seem to always be true that increased protein intake increases calcium absorption. In a study by Hunt et al. (Hunt et al. 2009), high protein intake (20\% of energy versus $10 \%$ ) did not increase calcium absorption when calcium intake 
was increased from 675 to $1520 \mathrm{mg} / \mathrm{d}$ in healthy postmenopausal women over a couple of weeks.

Increasing protein intake did not induce further increases in PTH- and 25-hydroxyvitamin D concentrations during BR. In healthy people, PTH and 25-hydroxyvitamin D concentrations decrease when serum calcium levels increase, to protect the organism from hypercalcemia and its effects on the body's systems (Wick 2007). Bed rest itself already caused a reduction in PTH concentrations. Additionally, urinary calcium excretion was increased and one might speculate that activation of these mechanisms would suffice to compensate for any further increase in bone resorption processes and concomitant effects on serum calcium concentrations. 25-hydroxyvitamin D concentrations only showed a trend of decreasing over time. 25-hydroxyvitamin $D$ is an indicator of vitamin $D$ supply and is the prerequisite for hydroxylation to 1,25 -dihydroxyvitamin D. Since the test subjects did not receive any vitamin D supplements in this study, the trend of a decrease was most likely caused by insufficient ultraviolet (UV) light, because the subjects had to stay indoors.

Increases in bone resorption markers with high protein intake have been shown in a shorter BR study of 4 weeks in male subjects. Zwart et al. (Zwart et al. 2005) applied (in addition to the approximately $1 \mathrm{~g}$ protein $/ \mathrm{kg} \mathrm{BM} / \mathrm{d}$ in the control group) about $0.6 \mathrm{~g}$ essential amino acids/kg BM/d along with $96 \mathrm{~g}$ of carbohydrates. These authors had similar results, including elevated calcium and NTX excretion as seen in our HiPROT subjects, in about 8 weeks of HDTBR. In their male subjects, urinary NTX excretion was already about $15 \%$ elevated in week 2 of HDTBR with amino acid supplementation. Zwart et al. also found a significant decrease in urinary $\mathrm{pH}$ as well as a positive correlation between sulfur and NTX excretion. From these increases in calcium and NTX, they concluded that a transient decrease in blood $\mathrm{pH}$ was playing a role in activating osteoclasts and increasing bone resorption. Although protein plays a major role in bone formation processes, it seems that providing protein with a high amount of sulfur-containing amino acids and not counteracting its potential acidic effect 
with alkaline precursors may decrease BMD (Alexy et al. 2005; Thorpe et al. 2008a). This observation is supported by the fact that in postmenopausal women, counteracting a potentially high renal acid load, when subjects consumed a Western-style diet, with potassium citrate over a period of only 12 weeks led to increased BMD (Jehle et al. 2006). Although we did not supplement merely essential amino acids and although we kept the ratio of $60 \%$ animal to $40 \%$ vegetable protein in the diet, one might speculate that an increase in the ratio of animal protein to potassium was also involved in increased bone resorption, as proposed by Zwart et al. (Zwart et al. 2004). Because dietary potassium intake was kept constant at an average intake level of about $3 \mathrm{~g} / \mathrm{d}$, the increase in animal protein intake led to a higher animal protein/potassium ratio, which might have caused bone resorption.

In preclinical studies, lowering protein intake for 14 days, from a diet containing $15 \%$ casein to one containing $2.5 \%$, impaired periosteal bone formation in cortical bone of rats (Bourrin et al. 2000), which may lead to decreased areal BMD as published earlier by that group (Ammann et al. 2000). In clinical trials, providing $0.7 \mathrm{~g}$ protein $/ \mathrm{kg} \mathrm{BM} /$ day as a low protein intake to young, healthy women led to secondary hyperparathyroidism (Kerstetter et al. 1997; Kerstetter et al. 2003a). Kerstetter et al. also stated in a review that "most of the epidemiological evidence shows that when other known dietary factors are controlled, those individuals who consume low protein diets have lower BMD" (Kerstetter et al. 2003a). In contrast, high protein intake induced increases in IGF-1 concentrations, resulting in increased lean body mass (Kerstetter et al. 2011; Zhu et al. 2011), and increased calcium and NTX excretion in young, healthy women, but no change in serum bAP or osteocalcin (Kerstetter et al. 1999). In the present study, IGF-1 concentration in HDTBR tended to be about $50 \%$ higher in the HiPROT subjects than in the controls. One would have expected this increase in IGF-1 to increase protein synthesis and as a result, at least maintain muscle mass and bone formation processes, so that bone formation would be unchanged from baseline. Effects of BR are nicely summarized in a review by Galvan et al. (Galvan et al. 2016) showing that postprandial muscle protein synthesis decreases by $45-50 \%$ after 14 
days of BR in older test subjects (Ferrando et al. 1997) or 7 days of full leg cast immobilization in young volunteers (Wall et al. 2016). It was also shown in the study by English et al (2016) that supplementing leucine, the amino acid that increases protein synthesis most effectively, had a significant effect on maintaining lean body mass during the early days of BR (first 7 days), but this effect of leucine levelled off thereafter (Galvan et al. 2016). Similar results were seen in postmenopausal women to whom growth hormone was administered for 1 year and whose IGF-1 levels were consistently higher than those of the placebo group. After 1 year, growth hormone had not increased BMD nor lean body mass (Friedlander et al. 2001). Insofar as this occurs, we might speculate that within 2 months of the beginning of BR, any beneficial effect of increased protein intake on bone formation might have either leveled off or-during lower mechanical loading—led to a resistance to IGF-1 as proposed by Inoue et al. (Inoue et al. 2000).

In inactivity such as BR or space flight, the loss of bone mass is mainly induced by reduced bone formation together with increased bone resorption (Inoue et al. 2000; Kim et al. 2003; LeBlanc et al. 2007; Smith et al. 1998; Vico et al. 2000). Providing higher total protein intake did not affect bone formation significantly. With respect to the analyzed bone resorption markers, TRAP concentration in fasting blood samples on HDTBR days 30 and 58 did not change significantly whereas urinary excretion of CTX and NTX per day in the same collection periods increased significantly. The differences in these trends may have different reasons. One caveat for the TRAP results might be that the analyses were carried out after each study campaign; the inter-assay variability might have induced higher overall variability of the results. One might also argue that taking one fasting blood sample for TRAP analyses might not be as representative for bone resorption as analyzing the total amount of resorption markers excreted over 24 hours. The latter may be particularly relevant when the study is carried out in a metabolic ward setting where subjects are well controlled and one can be assured that urine is completely collected for a 24 -hour period. In addition, we collected 24-hour urine pools on 2 consecutive days, checked for differences, and if they 
were not different used the mean values of those 2 days for further analyses. We are confident that the data on urinary excretion of bone resorption markers are reliable, and that the changes in bone resorption markers truly reflect changes in osteoclast activity. One may, however, speculate that TRAP concentration in blood might rather reflect the number of osteoclasts than their activity and therefore shows results different from those for the other bone resorption markers.

As mentioned earlier, this study was a multinational effort of several space agencies. The primary goal of this long-term HDTBR study was to demonstrate that increasing protein intake and supplementing branched-chain amino acids counteracts loss of muscle mass and strength in women during HDTBR. Beller et al. (2011) analysed BMD and BMC changes in these test subjects and -in line with our results in increased bone resorption markers- they have shown significant effects of high protein intake on BMC of whole body, hip, and leg. Furthermore, BMD and BMC were reduced in the sub-regions of the hip in the HiPROT group (Beller et al. 2011).

One might therefore speculate whether the further increase of bone resorption markers in the HiPROT group might be mainly induced in areas where osteoclasts are already activated because of lower mechanical loading such as in the hip and leg. In these areas the metabolites of high protein intake, in particular the sulfur- and phosphorus-containing amino acids (which may be metabolized into the respective acids) may encourage the already activated osteoclasts further or may induce further recruitment of osteoclasts. Because osteoclasts need a pH decrease in their extracellular environment to be activated (Arnett 2008), these acid precursors in amino acids might exacerbate the bone resorption process seen in the HiPROT group. It seems that under ambulatory conditions where similar amounts of protein were applied, such an effect of high protein intake to increase bone resorption was not found (Hunt et al. 2009; Thorpe \& Evans 2011; Thorpe et al. 2008b). This effect, which contrasts with our results presented here, might be due to different levels of physical activity. 
It might well be that in ambulatory conditions when bones are mechanically loaded, an increase in protein intake with adequate calcium intake affects bone in a positive way. However, if the osteoclasts are activated because of immobility, as in HDTBR, a transient and moderate decrease in blood $\mathrm{pH}$ that might be derived from high protein intake with adequate calcium intake might exacerbate bone resorption. 


\section{ACKNOWLEDGEMENTS}

We thank the 16 women who volunteered for this BR investigation for their excellent compliance in the study. We are also grateful to the study nurses, staff, and entire research team at the MEDES Space Clinic (Toulouse Rangueil Hospital) who coordinated the study for their exceptional care of the subjects during BR and exercise. We also thank G. Kraus, DLR Institute of Aerospace Medicine, Cologne, Germany, and the NASA Nutritional Biochemistry Laboratory, Houston TX, USA, for very careful biological analyses and A. Fischer, Profil Neuss, Germany, for the statistical analyses. We thank Jane Krauhs for editorial assistance. The study was supported by the European (ESA), the American (NASA), the French (CNES), and the German (DLR) space agencies. 


\section{STATEMENT OF AUTHORSHIP}

$\mathrm{MH}, \mathrm{NB}, \mathrm{PFM}$, and SMS developed the clinical trial protocol for this subtrial. GB, NB, and PFM co-organized the subtrial and analyses. MH, NB, PFM, and SG evaluated the data and supported the statistical analyses. All authors took part in data interpretation. $\mathrm{MH}$ wrote the manuscript, and all authors edited the manuscript. All authors approved the final article. 


\section{CONFLICT OF INTEREST STATEMENT}

The authors declare no conflict of interest with respect to the presented study. 


\section{References}

Alexy,U., Remer,T., Manz,F., Neu,C.M. \& Schoenau,E. 2005. Long-term protein intake and dietary potential renal acid load are associated with bone modeling and remodeling at the proximal radius in healthy children. Am. J. Clin. Nutr. 82: 1107-1114. PMID: 16280446.

Alibegovic,A.C., Hojbjerre,L., Sonne,M.P., van Hall,G., Stallknecht,B., Dela,F. \& Vaag,A. 2009. Impact of 9 days of bed rest on hepatic and peripheral insulin action, insulin secretion, and whole-body lipolysis in healthy young male offspring of patients with type 2 diabetes. Diabetes 58: 2749-2756. DOI:10.2337/db09-0369. PMID:19720789.

Ammann,P., Bonjour,J.P. \& Rizzoli,R. 2000. Essential amino acid supplements increase muscle weight, bone mass and bone strength in adult osteoporotic rats. J. Musculoskelet. Neuronal Interact. 1: 43-44. PMID:15758524.

Antonione,R., Caliandro,E., Zorat,F., Guarnieri,G., Heer,M. \& Biolo,G. 2008. Whey protein ingestion enhances postprandial anabolism during short-term bed rest in young men. J. Nutr. 138: 2212-2216. DOI:10.3945/jn.108.086462. PMID:18936221.

Arbeille,P., Kerbeci,P., Greaves,D., Schneider,S., Hargens,A. \& Hughson,R. 2007. Arterial and venous response to Tilt with LBNP test after a 60 day HDT bedrest (WISE study). J. Gravit. Physiol 14: 47-48. PMID:18372693.

Arbeille,P., Kerbeci,P., Mattar,L., Shoemaker,J.K. \& Hughson,R.L. 2008. WISE-2005: tibial and gastrocnemius vein and calf tissue response to LBNP after a 60-day bed rest with and without countermeasures. J. Appl. Physiol. 104: 938-943.

DOI:10.1152/japplphysiol.01021.2007. PMID:18202168.

Armbrecht,G., Belavy,D.L., Backstrom,M., Beller,G., Alexandre,C., Rizzoli,R. \&

Felsenberg,D. 2011. Trabecular and cortical bone density and architecture in women after 60 days of bed rest using high-resolution pQCT: WISE 2005. J. Bone Miner. Res. 26: 23992410. DOI:10.1002/jbmr.482. PMID:21812030.

Arnaud,S.B., Sherrard,D.J., Maloney,N., Whalen,R.T. \& Fung,P. 1992. Effects of 1-week head-down tilt bed rest on bone formation and the calcium endocrine system. Aviat. Space. Environ. Med. 63: 14-20. PMID:1550528.

Arnett,T.R. 2008. Extracellular pH regulates bone cell function. J. Nutr. 138: 415S-418S. PMID:14506899.

Baecker,N., Frings-Meuthen,P., Smith,S.M. \& Heer,M. 2010. Short-term high dietary calcium intake during bedrest has no effect on markers of bone turnover in healthy men. Nutrition 26: 522-527. DOI:10.1016/j.nut.2009.06.006. PMID:19765953.

Baecker,N., Tomic,A., Mika,C., Gotzmann,A., Platen,P., Gerzer,R. \& Heer,M. 2003. Bone resorption is induced on the second day of bedrest: results of a controlled crossover trial. J. Appl. Physiol 95: 977-982. DOI:10.1152/japplphysiol.00264.2003. PMID:12909597.

Bauer,J., Biolo,G., Cederholm,T., Cesari,M., Cruz-Jentoft,A.J., Morley,J.E., Phillips,S., Sieber,C., Stehle,P., Teta,D., Visvanathan,R., Volpi,E. \& Boirie,Y. 2013. Evidence-based recommendations for optimal dietary protein intake in older people: a position paper from the PROT-AGE Study Group. J. Am. Med. Dir. Assoc. 14: 542-559.

DOI:10.1016/j.jamda.2013.05.021. PMID:23867520. 
Beavers,K.R., Greaves,D.K., Arbeille,P. \& Hughson,R.L. 2007. WISE-2005: orthostatic tolerance is poorly predicted by acute changes in cardiovascular variables. J. Gravit. Physiol. 14: 63-64. PMID:18372701.

Beller,G., Belavy,D.L., Sun,L., Armbrecht,G., Alexandre,C. \& Felsenberg,D. 2011. WISE2005: bed-rest induced changes in bone mineral density in women during 60 days simulated microgravity. Bone 49: 858-866. DOI:10.1016/j.bone.2011.06.021. PMID:21723970.

Biolo,G., Ciocchi,B., Lebenstedt,M., Barazzoni,R., Zanetti,M., Platen,P., Heer,M. \& Guarnieri,G. 2004. Short-term bed rest impairs amino acid-induced protein anabolism in humans. J. Physiol. 558: 381-388. DOI:10.1113/jphysiol.2004.066365. PMID:15131238.

Biolo,G., Ciocchi,B., Stulle,M., Bosutti,A., Barazzoni,R., Zanetti,M., Antonione,R., Lebenstedt,M., Platen,P., Heer,M. \& Guarnieri,G. 2007. Calorie restriction accelerates the catabolism of lean body mass during 2 wk of bed rest. Am. J. Clin. Nutr 86: 366-372. PMID: 17684207.

Biolo,G., Maggi,S.P., Williams,B.D., Tipton,K.D. \& Wolfe,R.R. 1995. Increased rates of muscle protein turnover and amino acid transport after resistance exercise in humans. Am. J. Physiol. 268: E514-E520. PMID:7900797.

Bonjour,J.P. 2005. Dietary protein: an essential nutrient for bone health. J. Am. Coll. Nutr. 24: 526S-536S. PMID:16373952.

Bonjour,J.P. 2016. The dietary protein, IGF-I, skeletal health axis. Horm. Mol. Biol. Clin. Investig. 28: 39-53. DOI:10.1515/hmbci-2016-0003. PMID:26985688.

Bourrin,S., Ammann,P., Bonjour,J.P. \& Rizzoli,R. 2000. Dietary protein restriction lowers plasma insulin-like growth factor I (IGF-I), impairs cortical bone formation, and induces osteoblastic resistance to IGF-I in adult female rats. Endocrinology 141: 3149-3155. DOI:10.1210/endo.141.9.7633. PMID:10965885.

Bowen,J., Noakes,M. \& Clifton,P.M. 2004. A high dairy protein, high-calcium diet minimizes bone turnover in overweight adults during weight loss. J. Nutr. 134: 568-573.

PMID:14988448.

Buclin,T., Cosma,M., Appenzeller,M., Jacquet,A.F., Decosterd,L.A., Biollaz,J. \& Burckhardt,P. 2001. Diet acids and alkalis influence calcium retention in bone. Osteoporos. Int., 12, 493-499. Campbell,W.W. \& Tang,M. 2010. Protein intake, weight loss, and bone mineral density in postmenopausal women. J. Gerontol. A Biol. Sci. Med. Sci. 65: 1115-1122. DOI:10.1007/s001980170095. PMID:11446566.

Cao,J.J., Pasiakos,S.M., Margolis,L.M., Sauter,E.R., Whigham,L.D., McClung,J.P., Young,A.J. \& Combs,G.F., Jr. 2014. Calcium homeostasis and bone metabolic responses to high-protein diets during energy deficit in healthy young adults: a randomized controlled trial. Am. J. Clin. Nutr., 99, 400-407. DOI:10.3945/ajcn.113.073809. PMID:24284444.

Dawson-Hughes,B. 2003. Interaction of dietary calcium and protein in bone health in humans. J. Nutr. 133: 852S-854S. PMID:12612168.

Deutz,N.E., Bauer,J.M., Barazzoni,R., Biolo,G., Boirie,Y., Bosy-Westphal,A., Cederholm,T., Cruz-Jentoft,A., Krznaric,Z., Nair,K.S., Singer,P., Teta,D., Tipton,K. \& Calder,P.C. 2014.

Protein intake and exercise for optimal muscle function with aging: recommendations from the ESPEN Expert Group. Clin. Nutr. 33: 929-936. DOI:10.1016/j.clnu.2014.04.007.

PMID:24814383. 
Edgell,H., Zuj,K.A., Greaves,D.K., Shoemaker,J.K., Custaud,M.A., Kerbeci,P., Arbeille,P. \& Hughson,R.L. 2007. WISE-2005: adrenergic responses of women following 56-days, 6 degrees head-down bed rest with or without exercise countermeasures. Am. J. Physiol. Regul. Integr. Comp. Physiol. 293: R2343-R2352. DOI:10.1152/ajpregu.00187.2007. PMID:17928515.

English,K.L., Mettler,J.A., Ellison,J.B., Mamerow,M.M., Arentson-Lantz,E., Pattarini,J.M., Ploutz-Snyder,R., Sheffield-Moore,M. \& Paddon-Jones,D. 2016. Leucine partially protects muscle mass and function during bed rest in middle-aged adults. Am. J. Clin. Nutr. 103: 465473. DOI:10.3945/ajcn.115.112359. PMID:26718415.

English,K.L. \& Paddon-Jones,D. 2010. Protecting muscle mass and function in older adults during bed rest. Curr. Opin. Clin. Nutr. Metab. Care 13: 34-39.

DOI:10.1097/MCO.0b013e328333aa66. PMID:19898232.

Fenton,T.R., Lyon,A.W., Eliasziw,M., Tough,S.C. \& Hanley,D.A. 2009. Meta-analysis of the effect of the acid-ash hypothesis of osteoporosis on calcium balance. J. Bone Miner. Res. 24: 1835-1840. DOI: 10.1359/jbmr.090515. PMID:19419322.

Fenton,T.R., Tough,S.C., Lyon,A.W., Eliasziw,M. \& Hanley,D.A. 2011. Causal assessment of dietary acid load and bone disease: a systematic review \& meta-analysis applying Hill's epidemiologic criteria for causality. Nutr. J. 10: 41. DOI:10.1186/1475-2891-10-41. PMID:21529374.

Ferrando,A.A., Lane,H.W., Stuart,C.A., Davis-Street,J. \& Wolfe,R.R. 1996. Prolonged bed rest decreases skeletal muscle and whole body protein synthesis. Am. J. Physiol. 270: E627E633. PMID:8928769.

Ferrando,A.A., Tipton,K.D., Bamman,M.M. \& Wolfe,R.R. 1997. Resistance exercise maintains skeletal muscle protein synthesis during bed rest. J. Appl.Physiol. 82: 807-810. PMID:9074967.

Food and Nutrition Board \& Institute of Medicine 2005. Protein and Amino Acids. In: Dietary Reference Intakes for Energy, Carbohydrate, Fat, Fatty Acids, Cholesterol, Protein, and Amino Acids (Macronutrients), pp. 589-768. Washington D.C.: National Academies Press.

Frid,A.H., Nilsson,M., Holst,J.J. \& Bjorck,I.M. 2005. Effect of whey on blood glucose and insulin responses to composite breakfast and lunch meals in type 2 diabetic subjects. Am. J. Clin. Nutr. 82: 69-75. PMID:16002802.

Friedlander,A.L., Butterfield,G.E., Moynihan,S., Grillo,J., Pollack,M., Holloway,L., Friedman,L., Yesavage,J., Matthias,D., Lee,S., Marcus,R. \& Hoffman,A.R. 2001. One year of insulin-like growth factor I treatment does not affect bone density, body composition, or psychological measures in postmenopausal women. J. Clin. Endocrinol. Metab: 86: 14961503. DOI:10.1210/jcem.86.4.7377. PMID:11297574.

Gagne,N., Fischer,D., Greaves,D.K. \& Hughson,R.L. 2007. WISE-2005: developing a noninvasive method to monitor cardiovascular deconditioning. J. Gravit. Physiol. 14: 137-138. PMID:18372737.

Galvan,E., Arentson-Lantz,E., Lamon,S. \& Paddon-Jones,D. 2016. Protecting Skeletal Muscle with Protein and Amino Acid during Periods of Disuse. Nutrients 8. doi:10.3390. Ginty,F. 2003. Dietary protein and bone health. Proc. Nutr Soc. 62: 867-876. DOI: 10.3390/nu8070404. PMID:27376322. 
Guinet,P., Schneider,S.M., Macias,B.R., Watenpaugh,D.E., Hughson,R.L., Le Traon,A.P., Bansard,J.Y. \& Hargens,A.R. 2009. WISE-2005: effect of aerobic and resistive exercises on orthostatic tolerance during 60 days bed rest in women. Eur. J Appl. Physiol. 106: 217-227. Heaney,R.P. \& Layman,D.K. 2008. Amount and type of protein influences bone health. Am. J. Clin. Nutr. 87: 1567S-1570S. DOI:10.1007/s00421-009-1009-6. PMID:19247686.

Hodges,G.J., Mattar,L., Zuj,K.A., Greaves,D.K., Arbeille,P.M., Hughson,R.L. \& Shoemaker,J.K. 2010. WISE-2005: prolongation of left ventricular pre-ejection period with 56 days head-down bed rest in women. Exp. Physiol. 95:1081-1088.

DOI:10.1113/expphysiol.2010.054254. PMID:20696784.

Hunt,J.R., Johnson,L.K. \& Fariba Roughead,Z.K. 2009. Dietary protein and calcium interact to influence calcium retention: a controlled feeding study. Am. J. Clin. Nutr. 89: 1357-1365. DOI:10.3945/ajcn.2008.27238. PMID:19279077.

Ihle,R. \& Loucks,A.B. 2004. Dose-response relationships between energy availability and bone turnover in young exercising women. J. Bone Miner. Res. 19: 1231-1240.

DOI:10.1359/JBMR.040410. PMID:15231009.

Inoue,M., Tanaka,H., Moriwake,T., Oka,M., Sekiguchi,C. \& Seino,Y. 2000. Altered biochemical markers of bone turnover in humans during 120 days of bed rest. Bone 26: 281286. PMID:10710002.

Institute of Medicine 2002. Dietary Reference Intakes for Energy, Carbohydrate, Fiber, Fat, Fatty Acids, Cholesterol, Protein, and Amino Acids (Macronutrients). Washington DC: National Academies Press.

Institute of Medicine 2004. Dietary Reference Intakes for Water, Potassium, Sodium, Chloride, and Sulfate. Washington DC: National Academies Press.

Institute of Medicine 2011. Dietary Reference Intakes for Calcium and Vitamin D. Washington DC: National Academies Press.

Jehle,S., Zanetti,A., Muser,J., Hulter,H.N. \& Krapf,R. 2006. Partial neutralization of the acidogenic Western diet with potassium citrate increases bone mass in postmenopausal women with osteopenia. J. Am. Soc. Nephrol. 17: 3213-3222. DOI:

10.1681/ASN.2006030233. PMID:17035614.

Kerbeci,P., Shoemaker,K., Hughson,R., Roncin,A. \& Arbeille,P. 2007. Tibial and gastrocnemian vein response to LBNP after a 60 day bedrest with and without countermeasures (WISE study). J. Gravit. Physiol 14: 57-58. PMID:18372698.

Kerstetter,J.E., Caseria,D.M., Mitnick,M.E., Ellison,A.F., Gay,L.F., Liskov,T.A., Carpenter,T.O. \& Insogna,K.L. 1997. Increased circulating concentrations of parathyroid hormone in healthy, young women consuming a protein-restricted diet. Am. J. Clin. Nutr. 66: 1188-1196. PMID:9356538.

Kerstetter,J.E., Kenny,A.M. \& Insogna,K.L. 2011. Dietary protein and skeletal health: a review of recent human research. Curr. Opin. Lipidol. 22: 16-20.

DOI:10.1097/MOL.0b013e3283419441. PMID:21102327.

Kerstetter,J.E., Mitnick,M.E., Gundberg,C.M., Caseria,D.M., Ellison,A.F., Carpenter,T.O. \& Insogna,K.L. 1999. Changes in bone turnover in young women consuming different levels of dietary protein. J. Clin. Endocrinol. Metab. 84: 1052-1055. DOI:10.1210/jcem.84.3.5552. PMID:10084594. 
Kerstetter,J.E., O'Brien,K.O., Caseria,D.M., Wall,D.E. \& Insogna,K.L. 2005. The impact of dietary protein on calcium absorption and kinetic measures of bone turnover in women. J. Clin. Endocrinol. Metab. 90: 26-31. DOI:10.1210/jc.2004-0179. PMID:15546911.

Kerstetter,J.E., O'Brien,K.O. \& Insogna,K.L. 2003a. Low protein intake: the impact on calcium and bone homeostasis in humans. J. Nutr. 133: 855S-861S. PMID:12612169.

Kerstetter,J.E., O'Brien,K.O. \& Insogna,K.L. 2003b. Dietary protein, calcium metabolism, and skeletal homeostasis revisited. Am. J. Clin. Nutr. 78: 584S-592S. PMID:12936953.

Kim,H., Iwasaki,K., Miyake,T., Shiozawa,T., Nozaki,S. \& Yajima,K. 2003. Changes in bone turnover markers during 14-day 6 degrees head-down bed rest. J. Bone Miner. Metab: 21: 311-315. DOI:10.1007/s00774-003-0426-6. PMID:12928833.

Kraut,J.A. \& Coburn,J.W. 1994. Bone, acid, and osteoporosis. N. Engl. J. Med. 330: 18211822. DOI:10.1056/NEJM199406233302510. PMID:8190161.

Lang,T., LeBlanc,A., Evans,H., Lu,Y., Genant,H. \& Yu,A. 2004. Cortical and trabecular bone mineral loss from the spine and hip in long-duration spaceflight. J. Bone Miner. Res. 19: 1006-1012. DOI:10.1359/JBMR.040307. PMID:15125798.

Lanham-New,S.A. 2008. The balance of bone health: tipping the scales in favor of potassium-rich, bicarbonate-rich foods. J. Nutr. 138: 172S-177S. PMID:18156420.

LeBlanc,A., Schneider,V., Spector,E., Evans,H., Rowe,R., Lane,H., Demers,L. \& Lipton,A. 1995. Calcium absorption, endogenous excretion, and endocrine changes during and after long-term bed rest. Bone 16: 301S-304S. PMID:7626318.

LeBlanc,A.D., Spector,E.R., Evans,H.J. \& Sibonga,J.D. 2007. Skeletal responses to space flight and the bed rest analog: a review. J. Musculoskelet. Neuronal Interact. 7: 33-47. PMID:17396004.

MacDonald,H.M., New,S.A., Fraser,W.D., Campbell,M.K. \& Reid,D.M. 2005. Low dietary potassium intakes and high dietary estimates of net endogenous acid production are associated with low bone mineral density in premenopausal women and increased markers of bone resorption in postmenopausal women. Am. J. Clin. Nutr. 81: 923-933.

PMID:15817873.

Massey,L.K. 2003. Dietary animal and plant protein and human bone health: a whole foods approach. J. Nutr. 133: 862S-865S. PMID:12612170.

Moore,D.R. 2014. Keeping older muscle "young" through dietary protein and physical activity. Adv. Nutr. 5: 599S-607S. PMID:25469405.

Morgan,J.L., Heer,M., Hargens,A.R., Macias,B.R., Hudson,E.K., Shackelford,L.C., Zwart,S.R. \& Smith,S.M. 2014. Sex specific responses of bone metabolism and renal stone risk during bed rest. Physiological reports 2: e12119. DOI:10.14814/phy2.12119:

PMID:25107989.

Murray,T.M. 1996. Prevention and management of osteoporosis: consensus statements from the Scientific Advisory Board of the Osteoporosis Society of Canada. 4. Calcium nutrition and osteoporosis. Can. Med. Assoc. J. 155: 935-939. PMID:8837545.

New,S.A., MacDonald,H.M., Campbell,M.K., Martin,J.C., Garton,M.J., Robins,S.P. \& Reid,D.M. 2004. Lower estimates of net endogenous non-carbonic acid production are 
positively associated with indexes of bone health in premenopausal and perimenopausal women. Am. J. Clin. Nutr. 79: 131-138. PMID:14684409.

Nicoll,R. \& McLaren,H.J. 2014. The acid-ash hypothesis revisited: a reassessment of the impact of dietary acidity on bone. J. Bone Miner. Metab. 32: 469-475. DOI:10.1007/s00774014-0571-0. PMID:24557632.

Remer,T., Krupp,D. \& Shi,L. 2014. Dietary protein's and dietary acid load's influence on bone health. Crit. Rev. Food Sci. Nutr. 54: 1140-1150. DOI:10.1080/10408398.2011.627519. PMID:24499146.

Remer,T. \& Manz,F. 1995. Potential renal acid load of foods and its influence on urine pH. J. Am. Diet. Assoc. 95: 791-797. DOI:10.1016/S0002-8223(95)00219-7. PMID:7797810.

Rietman,A., Schwarz,J., Tome,D., Kok,F.J. \& Mensink,M. 2014. High dietary protein intake, reducing or eliciting insulin resistance? Eur. J. Clin. Nutr. 68: 973-979.

DOI:10.1038/ejcn.2014.123. PMID:24986822.

Rouy,E., Vico,L., Laroche,N., Benoit,V., Rousseau,B., Blachier,F., Tome,D. \& Blais,A. 2014. Protein quality affects bone status during moderate protein restriction in growing mice. Bone 59: 7-13. DOI:10.1016/j.bone.2013.10.013. PMID:24495359.

Sahni,S., Cupples,L.A., McLean,R.R., Tucker,K.L., Broe,K.E., Kiel,D.P. \& Hannan,M.T. 2010. Protective effect of high protein and calcium intake on the risk of hip fracture in the Framingham offspring cohort. J. Bone Miner. Res. 25: 2770-2776. DOI:10.1002/jbmr.194. PMID:20662074.

SAS. [9.3]. 2011. Cary, NC, USA, SAS Institute Inc.

Schneider,S.M., Lee,S.M., Macias,B.R., Watenpaugh,D.E. \& Hargens,A.R. 2009. WISE2005: exercise and nutrition countermeasures for upright $\mathrm{VO}_{2}$ pk during bed rest. Med. Sci. Sports Exerc. 41: 2165-2176. DOI:10.1249/MSS.0b013e3181aa04e5. PMID:19915502.

Smith,S.M., Heer,M.A., Shackelford,L.C., Sibonga,J.D., Ploutz-Snyder,L. \& Zwart,S.R. 2012. Benefits for bone from resistance exercise and nutrition in long-duration spaceflight: Evidence from biochemistry and densitometry. J. Bone Miner. Res. 27: 1896-1906. DOI:10.1002/jbmr.1647. PMID:22549960.

Smith,S.M., Nillen,J.L., LeBlanc,A., Lipton,A., Demers,L.M., Lane,H.W. \& Leach,C.S. 1998. Collagen cross-link excretion during space flight and bed rest. J. Clin. Endocrinol. Metab. 83: 3584-3591. DOI:10.1210/jcem.83.10.5169. PMID:9768669.

Smith,S.M., Zwart,S.R., Heer,M., Hudson,E.K., Shackelford,L. \& Morgan,J.L. 2014. Men and Women in Space: Bone Loss and Kidney Stone Risk after Long-Duration Spaceflight. J. Bone Miner. Res. 29:1639-1645. DOI: 10.1002/jbmr.2185.PMID:24470067.

Smith,S.M., Zwart,S.R., Heer,M., Lee,S.M., Baecker,N., Meuche,S., Macias,B.R., Shackelford,L.C., Schneider,S. \& Hargens,A.R. 2008. WISE-2005: Supine treadmill exercise within lower body negative pressure and flywheel resistive exercise as a countermeasure to bed rest-induced bone loss in women during 60-day simulated microgravity. Bone 42: $572-$ 581. DOI:10.1016/j.bone.2007.11.015. PMID:18249055. 
Thorpe,M., Mojtahedi,M.C., Chapman-Novakofski,K., McAuley,E. \& Evans,E.M. 2008a. A positive association of lumbar spine bone mineral density with dietary protein is suppressed by a negative association with protein sulfur. J. Nutr. 138: 80-85. PMID:18156408.

Thorpe,M.P. \& Evans,E.M. 2011. Dietary protein and bone health: harmonizing conflicting theories. Nutr. Rev. 69: 215-230. DOI:10.1111/j.1753-4887.2011.00379.x. PMID:21457266.

Thorpe,M.P., Jacobson,E.H., Layman,D.K., He,X., Kris-Etherton,P.M. \& Evans,E.M. 2008b. A diet high in protein, dairy, and calcium attenuates bone loss over twelve months of weight loss and maintenance relative to a conventional high-carbohydrate diet in adults. J. Nutr. 138: 1096-1100. PMID:18492840.

Trudel,G., Payne,M., Madler,B., Ramachandran,N., Lecompte,M., Wade,C., Biolo,G., Blanc,S., Hughson,R., Bear,L. \& Uhthoff,H.K. 2009. Bone marrow fat accumulation after 60 days of bed rest persisted 1 year after activities were resumed along with hemopoietic stimulation: the Women International Space Simulation for Exploration study. J. Appl. Physiol. 107: 540-548. DOI:10.1152/japplphysiol.91530.2008. PMID:19478189.

van der Wiel,H.E., Lips,P., Nauta,J., Netelenbos,J.C. \& Hazenberg,G.J. 1991. Biochemical parameters of bone turnover during ten days of bed rest and subsequent mobilization. Bone Miner. 13: 123-129. PMID:2059676.

Vico,L., Collet,P., Guignandon,A., Lafage-Proust,M.H., Thomas,T., Rehaillia,M. \& Alexandre,C. 2000. Effects of long-term microgravity exposure on cancellous and cortical weight-bearing bones of cosmonauts. Lancet 355: 1607-1611. PMID:10821365.

Wall,B.T., Dirks,M.L., Snijders,T., van Dijk,J.-W., Fritsch,M., Verdijk,L.B. \& van Loon, L.J.C. 2016. Short-term muscle disuse lowers myofibrillar protein synthesis rates and induces anabolic resistance to protein ingestion. Am. J. Physiol. Endoc. Metab. 310: E137-E147. DOI:10.1152/ajpendo.00227.2015. PMID:26578714.

Wick,J.Y. 2007. Immobilization hypercalcemia in the elderly. Consult. Pharm. 22: 892-905. PMID:18198977.

Wolfe,R.R., Miller,S.L. \& Miller,K.B. 2008. Optimal protein intake in the elderly. Clin. Nutr. 27: 675-684. DOI:10.1016/j.clnu.2008.06.008. PMID:18819733.

Wynn,E., Krieg,M.A., Lanham-New,S.A. \& Burckhardt,P. 2010. Postgraduate Symposium: Positive influence of nutritional alkalinity on bone health. Proc. Nutr. Soc. 69: 166-173. DOI:10.1017/S002966510999173X. PMID:19954569.

Yanagibori,R., Suzuki,Y., Kawakubo,K., Kondo,K., Iwamoto,T., Itakura,H., Makita,Y., Sekiguchi,C., Gunji,A. \& Kondou,K. 1997. The effects of 20 days bed rest on serum lipids and lipoprotein concentrations in healthy young subjects. J. Gravit. Physiol. 4: S82-S90. PMID:11541183.

Zerwekh,J.E., Ruml,L.A., Gottschalk,F. \& Pak,C.Y. 1998. The effects of twelve weeks of bed rest on bone histology, biochemical markers of bone turnover, and calcium homeostasis in eleven normal subjects. J. Bone Miner. Res. 13: 1594-1601.

DOI:10.1359/jbmr.1998.13.10.1594. PMID:9783548.

Zhu,K., Meng,X., Kerr,D.A., Devine,A., Solah,V., Binns,C.W. \& Prince,R.L. 2011. The effects of a two-year randomized, controlled trial of whey protein supplementation on bone structure, IGF-1, and urinary calcium excretion in older postmenopausal women. J. Bone Miner. Res. 26: 2298-2306. DOI:10.1002/jbmr.429. PMID:21590739. 
Zuj,K.A., Greaves,D.K. \& Hughson,R.L. 2007. WISE-2005: reduced cerebral blood flow velocity with nitroglycerin--comparison with common carotid artery blood flow. J. Gravit. Physiol. 14: 65-66. PMID:18372702.

Zwart,S.R., Hargens,A.R. \& Smith,S.M. 2004. The ratio of animal protein intake to potassium intake is a predictor of bone resorption in space flight analogues and in ambulatory subjects. Am. J. Clin. Nutr. 80: 1058-1065. PMID:15447920.

Zwart,S.R., Davis-Street,J.E., Paddon-Jones,D., Ferrando,A.A., Wolfe,R.R. \& Smith,S.M. 2005. Amino acid supplementation alters bone metabolism during simulated weightlessness. J. Appl. Physiol. 99: 134-140. DOI:10.1152/japplphysiol.01406.2004. PMID:15691900. 
Table 1: Nutrient intake of standardized nutrients in the control and high protein intake (HiPROT) group during the different study phases. Values are mean $\pm \mathrm{SD}$.

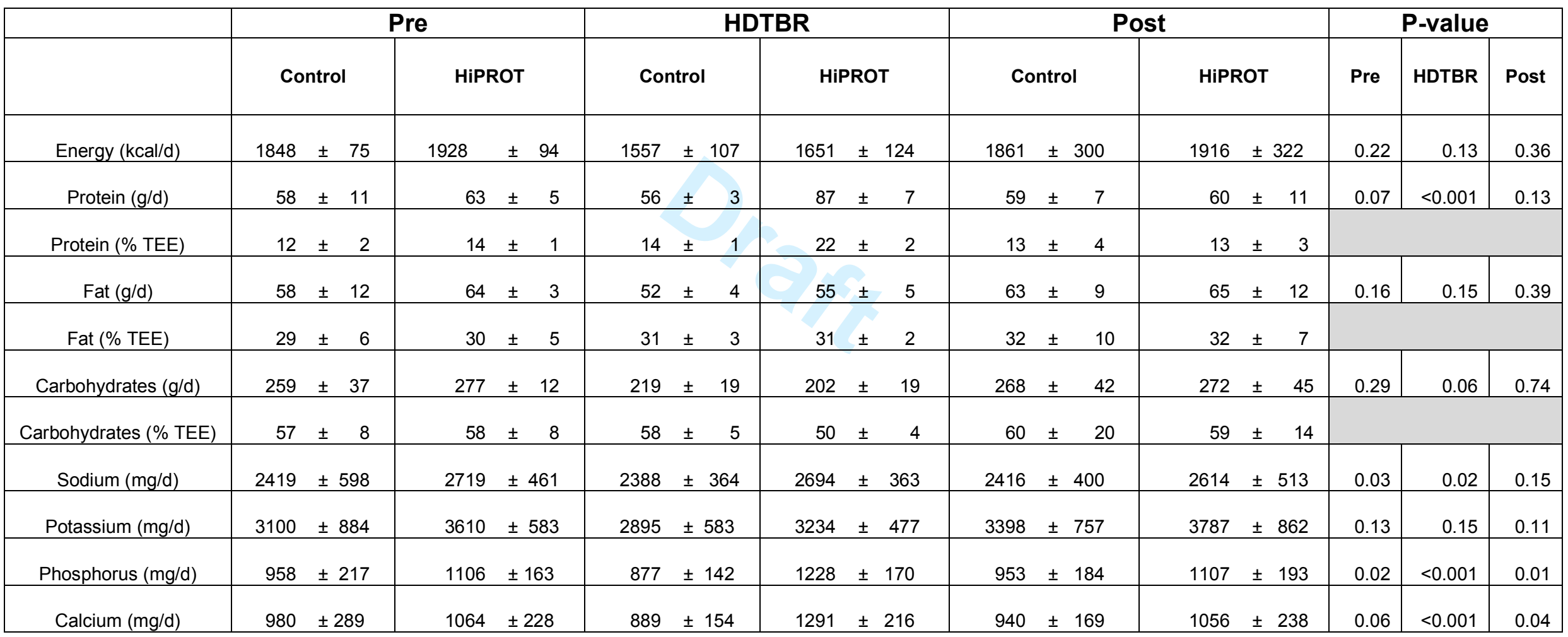


Table 2a: Examples of meals of the control and high protein intake (HiPROT) group provided during the 60-day HDTBR study. The choice of ingredients of this example day, plus the supplement of branched-chain amino acids, achieved the levels of high protein intake. On days when high protein intake was not achieved by ingredients, protein powder was added to the daily meals.

\begin{tabular}{|l|l|l|l|l|l|l|l|}
\hline \multicolumn{2}{|c|}{ Breakfast } & \multicolumn{2}{c|}{ Lunch } & \multicolumn{2}{c|}{ Snack } & \multicolumn{2}{c|}{ Dinner } \\
\hline Almonds & HiPROT & \multicolumn{1}{|c|}{ Control } & HiPROT & \multicolumn{1}{c|}{ Control } & HiPROT & Control & HiPROT \\
\hline Cereals & Butter & Summus & Hummus & Banana & $\begin{array}{l}\text { Fromage } \\
\text { blanc }\end{array}$ & Asparagus & Asparagus \\
\hline Hazelnut & Milk & $\begin{array}{l}\text { Sauce } \\
\text { Bearnaise }\end{array}$ & $\begin{array}{l}\text { Sauce } \\
\text { Bearnaise }\end{array}$ & Bread & & Light sauce & Light sauce \\
\hline Yoghurt & Sugar & Ratatouille & Ratatouille & & Basmati rice & Basmati rice \\
\hline Apple juice & Orange juice & Salt & Salt & & Emmental & $\begin{array}{l}\text { Emmental } \\
\text { cheese }\end{array}$ \\
\hline & & Bread & Bread & & Banana & Banana \\
\hline & & Cheese & $\begin{array}{l}\text { Fromage } \\
\text { blanc }\end{array}$ & & & & \\
\hline
\end{tabular}


Table 2b: List of the main ingredients for the creation of different dishes for the 60-day HDTBR study.

\begin{tabular}{|l|l|l|l|l|l|}
\hline \multicolumn{2}{|c|}{ Fruit and Vegetables } & \multicolumn{1}{|c|}{$\begin{array}{c}\text { Milk and Milk } \\
\text { Products }\end{array}$} & \multicolumn{1}{c|}{ Meat, Fish } & \multicolumn{1}{c|}{$\begin{array}{c}\text { Bread and } \\
\text { Cereals }\end{array}$} & $\begin{array}{c}\text { Side dishes \& } \\
\text { finished meals }\end{array}$ \\
\hline Apple & Kidney Beans & Camembert & Duck & $\begin{array}{c}\text { Different kinds of } \\
\text { bread }\end{array}$ & Crêpe \\
\cline { 2 - 6 } Asparagus & Kiwi & Cantal & Ground beef & Gnocci \\
\hline Artichoke & Lettuce & Comte & Pork & Muesli & Pasta \\
\hline Beetroot & Orange & Cheese & Salmon & Rice \\
\hline Banana & Peach & Edam & Tuna & \\
\hline Broccoli & Pear & Emmental & Turkey & & \\
\hline Carrot & Peppers & Fromage blanc & & & \\
\hline Cauliflower & Pineapple & Gouda & & & \\
\hline Chick Peas & Potatoe & Milk & & & \\
\hline Cucumber & Prunes & Milkshake & & & \\
\hline Corn & Spinach & Tome & & & \\
\hline Endive & Tomato & Yoghurt & & & \\
\hline Grapefruit & Zucchini & & & & \\
\hline Green Beans & & & & & \\
\hline
\end{tabular}


Table 3: $\quad$ Effect of high protein intake $(1.45 \mathrm{~g} / \mathrm{kg} \mathrm{BM} / \mathrm{d}$ plus a branched-chain amino acid supplementation of $0.72 \mathrm{~g}$ per day) during 60 days of HDTBR in women. Pre, before BR; HDT30, head-down-tilt BR, day 30; HDT58, head-down-tilt BR, day 58; Post, after BR; HiPROT, group with high protein intake (about $1.6 \mathrm{~g} / \mathrm{kg} \mathrm{BM} / \mathrm{d}$ ). Data are mean values \pm SD.

\begin{tabular}{|c|c|c|c|c|c|c|c|c|c|c|c|}
\hline & \multicolumn{2}{|c|}{ Pre } & \multicolumn{2}{|c|}{ HDT30 } & \multicolumn{2}{|c|}{ HDT58 } & \multicolumn{2}{|c|}{ Post } & \multicolumn{3}{|c|}{ P-values for } \\
\hline & Control & $\begin{array}{c}\text { Protein } \\
\text { supplemented }\end{array}$ & Control & $\begin{array}{c}\text { Protein } \\
\text { supplemented }\end{array}$ & Control & $\begin{array}{c}\text { Protein } \\
\text { supplemented }\end{array}$ & Control & $\begin{array}{c}\text { Protein } \\
\text { supplemented }\end{array}$ & time & $\begin{array}{l}\text { treat- } \\
\text { ment }\end{array}$ & $\begin{array}{l}\text { Inter- } \\
\text { action }\end{array}$ \\
\hline $\begin{array}{l}\text { Calcium } \\
(\mathrm{mmol} / \mathrm{L})\end{array}$ & $2.20 \pm 0.02$ & $2.31 \pm 0.02$ & $2.30 \pm 0.02$ & $2.34 \pm 0.02$ & $2.33 \pm 0.02$ & $2.37 \pm 0.03$ & $2.24 \pm 0.03$ & $2.30 \pm 0.03$ & $<0.001$ & 0.01 & 0.13 \\
\hline $\begin{array}{c}\text { Phosphate } \\
(\mathrm{mmol} / \mathrm{L})\end{array}$ & $1.20 \pm 0.07$ & $1.35 \pm 0.03$ & $1.39 \pm 0.06$ & $1.44 \pm 0.04$ & $1.43 \pm 0.06$ & $1.47 \pm 0.04$ & $1.47 \pm 0.03$ & $1.50 \pm 0.05$ & $<0.001$ & 0.31 & 0.08 \\
\hline $\begin{array}{c}\text { IGF-1 } \\
(\mathrm{ng} / \mathrm{mL})\end{array}$ & $449 \pm 42$ & $483 \pm 63$ & $472 \pm 52$ & $614 \pm 66$ & $456 \quad \pm 47$ & $625 \pm 68$ & $277 \pm 33$ & $324 \pm 42$ & $<0.001$ & 0.08 & 0.06 \\
\hline $\begin{array}{l}\text { PTH intact } \\
(\mathrm{pg} / \mathrm{mL})\end{array}$ & $38.3 \pm 6.4$ & $26.7 \pm 6.3$ & $17.2 \pm 6.6$ & $23.2 \pm 5.4$ & $44.6 \pm 14.5$ & $24.2 \pm 7.5$ & $37.5 \pm 13.9$ & $54.2 \pm 13.5$ & 0.02 & 0.83 & 0.58 \\
\hline $\begin{array}{c}25-\mathrm{OH} \\
\text { Vitamin D } \\
(\mathrm{nmol} / \mathrm{L})\end{array}$ & $44.4 \pm 5.5$ & $39.6 \pm 6.6$ & $41.9 \pm 5.5$ & $34.0 \pm 5.5$ & $39.0 \pm 6.2$ & $32.3 \pm 4.8$ & \pm 3.6 & $31.4 \pm 5.4$ & 0.06 & 0.39 & 0.79 \\
\hline $\begin{array}{c}\text { PINP } \\
(\mathrm{ng} / \mathrm{mL})\end{array}$ & $69.3 \pm 9.7$ & $78.1 \pm 8.9$ & $61.9 \pm 7.4$ & $76.8 \pm 7.4$ & $68.1 \pm 7.6$ & $78.3 \pm 10.3$ & $77.3 \pm 7.6$ & $96.3 \pm 13.7$ & $<0.001$ & 0.33 & 0.68 \\
\hline bAP (U/L) & $22.2 \pm 3.0$ & $24.5 \pm 3.7$ & $22.6 \pm 2.6$ & $30.3 \quad \pm 4.8$ & $22.4 \pm 2.5$ & $28.3 \quad \pm 4.4$ & $19.9 \pm 3.2$ & $27.4 \quad \pm 6.0$ & 0.56 & 0.22 & 0.56 \\
\hline $\begin{array}{l}\text { Osteocalcin } \\
(\mathrm{ng} / \mathrm{mL})\end{array}$ & $12.1 \pm 0.9$ & $12.7 \pm 1.6$ & $13.3 \pm 1.0$ & $13.1 \pm 1.0$ & $12.5 \pm 0.8$ & $13.0 \pm 1.0$ & $12.1 \pm 0.9$ & $12.3 \pm 1.1$ & 0.21 & 0.84 & 0.90 \\
\hline $\begin{array}{c}\text { TRAP } \\
(\mathrm{ng} / \mathrm{mL})\end{array}$ & $2.78 \pm 0.21$ & $3.13 \pm 0.27$ & $3.69 \pm 0.26$ & $4.26 \pm 0.51$ & $3.75 \pm 0.29$ & $4.11 \pm 0.50$ & $3.23 \pm 0.26$ & $3.54 \pm 0.37$ & $<0.001$ & 0.39 & 0.99 \\
\hline
\end{tabular}




\section{FIGURE LEGENDS}

Figure 1: Body mass and composition of women before, during, and after head-down-tilt (HDT) bed rest (BR) without (CON) or with (HiPROT) high protein intake.

Top: Daily body mass data in healthy women subjected to either 60 days of HDTBR (CON, open circles) or 60 days of HDTBR plus high protein intake (HiPROT, triangles). The data are means \pm SD. Body mass was significantly different between groups before HDTBR $\left({ }^{*} p<0.05\right)$.

Bottom left: Total body fat mass measured by dual-energy X-ray absorptiometry in healthy women before HDTBR, after about 30 days of HDTBR, and 3 days after they were subjected to either 60 days of HDTBR (CON, black bars) or 60 days of HDTBR plus high protein intake (HiPROT, gray bars). The data are means \pm SD. Total body fat decreased significantly in the control group $\left({ }^{*} \mathrm{p}<0.05\right)$.

Bottom right: Total lean body mass measured by dual-energy X-ray absorptiometry in healthy women before HDTBR, after about 30 days of HDTBR, and 3 days after they were subjected to either 60 days of HDTBR (CON, black bars) or 60 days of HDTBR plus high protein intake (HiPROT, gray bars). The data are means \pm SD. Lean body mass was significantly different between groups before HDTBR $\left({ }^{*} p<0.05\right)$.

Figure 2: Urinary excretion of calcium and bone resorption markers by women before, during, and after HDTBR without (CON) or with (HiPROT) high protein intake. Top: Urinary calcium excretion (UCaV) per day in healthy women subjected to either 60 days of HDTBR (CON, black bars) or 60 days of HDTBR plus high protein intake (HiPROT, gray bars). High protein intake induced significant increases in UCaV $(p<0.001)$. ${ }^{*} p<0.05$. The data are means $\pm S D$.

Middle: Urinary excretion of the bone resorption marker C-telopeptide (UCTX) per day in healthy women subjected to either 60 days of HDTBR (CON, black bars) or 60 days of HDTBR plus high protein intake (HiPROT, gray bars). High protein 
intake induced significant increases in UCTX $(p<0.001) .{ }^{* *} p<0.01$. The data are means $\pm S D$.

Bottom: Urinary excretion of the bone resorption marker N-telopeptide (UNTX) per day in healthy women subjected to either 60 days of HDTBR (CON, black bars) or 60 days of HDTBR plus high protein intake (HiPROT, gray bars). High protein intake induced significant increases in UNTX (p<0.001). ${ }^{*} p<0.05,{ }^{* * *} p<0.001$. The data are means $\pm S D$. 

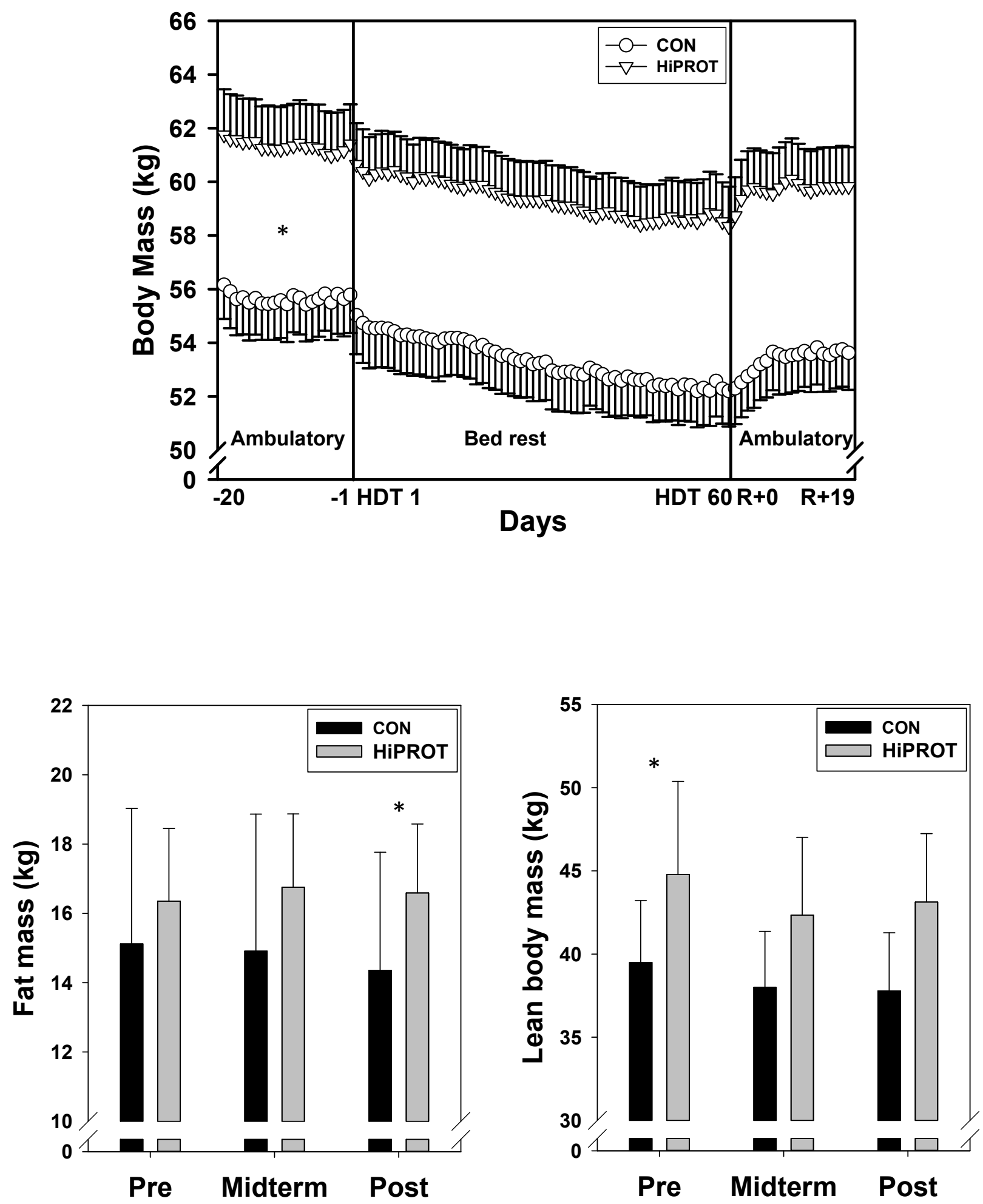

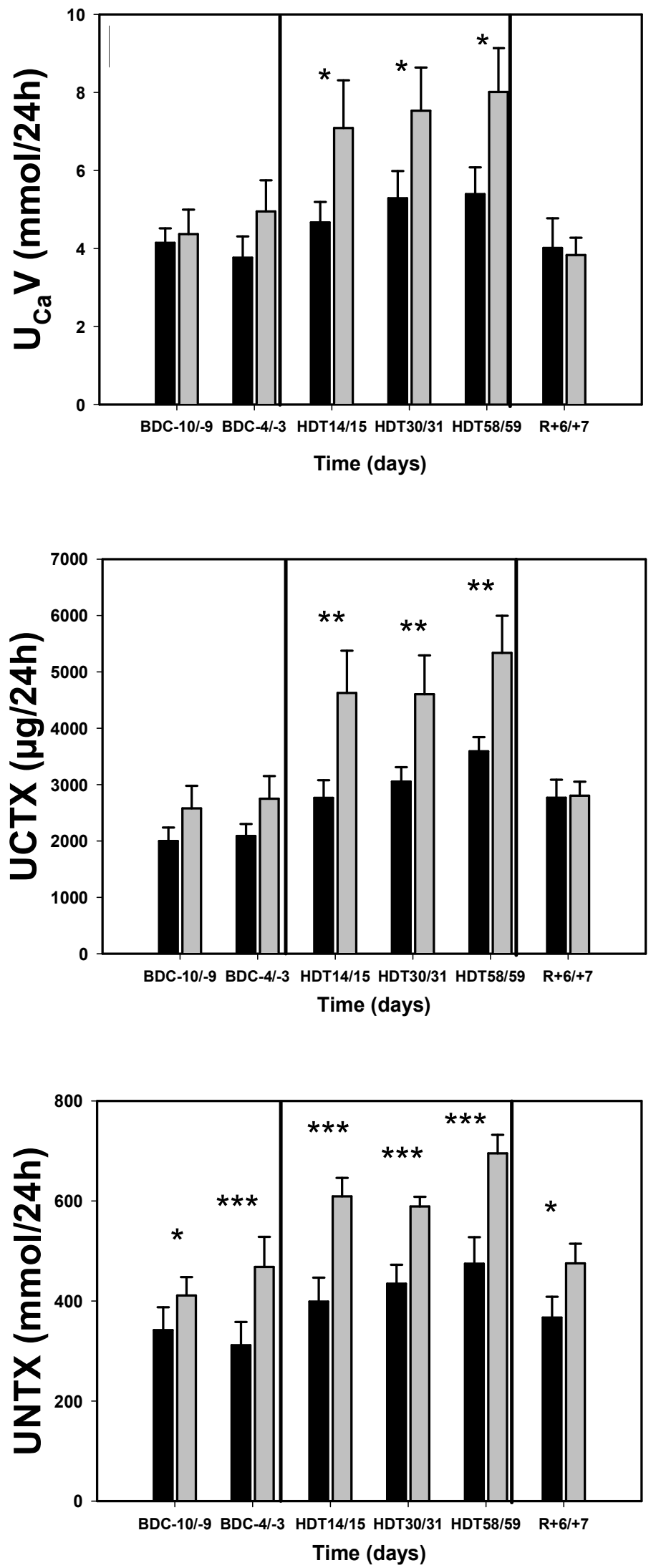